\begin{tabular}{|c|c|}
\hline & $\begin{array}{c}\text { Mobilya ve Ahşap Malzeme Araştırmaları Dergisi } \\
\text { Furniture and Wooden Material Research Journal } \\
\text { Araştırma Makalesi - Research Article } \quad 2018-1(2), 62-77\end{array}$
\end{tabular}

\title{
Ahşap ve mimarlık eğitimi: İstanbul örneği
}

Gül Yücel

$\ddot{\mathbf{O} z}$

Çalışma, ahşabın mimarlık lisans eğitimindeki yerinin incelenmesi amacıyla gerçekleştirilmiştir. Mimarlık meslek eğitimi ahşabın tasarım ve koruma ile bütünleştirilmesinde temel oluşturmaktadır. İstanbul, ahşap mimarlık mirası ve mimarlık eğitiminde okul ve kontenjan açısından merkez konumdadır. Araştırma İstanbul'da bulunan üniversitelerin mimarlık bölümleri lisans düzeyi sınırlılığında gerçekleştirilmiştir. Ahşapla ilgili bağımsız ders araştırmasında; ders kategorisi, bulunduğu yarıyıl, kredisi, ders süresi, uygulama, teorik ve laboratuar bilgisi ve ders içeriği incelenmiştir. Ders içeriğinde yapı malzemesi ahşap ve ana maddesi ağaçların yapısal özellikleri, ahşabın yapıda kullanım alanları, ahşap mimari miras, taşıyıcı sistem, standart ve yönetmelikler dikkate alınmıştır. Mimarlık müfredatında ahşap, seçmeli grupta ve teorik ders olarak yer bulmaktadır. Ahşap konulu ders içerikleri ahşabın ve ana kaynağı ağacın özelliklerine odaklıdır. Yapılan araştırma sonuçları, mimarlık eğitiminde ahşap ve ahşap yapıların daha fazla yer almasına ihtiyaç olduğunu göstermektedir.

Anahtar kelimeler: Ahşap, ahşap mimarlık mirası, mimarlık eğitimi, İstanbul

\section{Wood and architectural education: Istanbul case}

\begin{abstract}
The study is carried out to examine the place of wooden material in architectural education at undergraduate level. The architectural vocational education is the bases for integration of wood with design and conservation. Istanbul is as the center of wooden architecture heritage and architecture education. Research is restricted with universities, located in Istanbul, including undergraduate level architectural education. In the independent course research on wooden; course category, semester, credit, course duration, application, theoretical and laboratory knowledge and course content are examined. In the content of the course investigation; the structural properties of wood, wooden building materials, usage areas of wood in the structure, wooden architectural heritage, carrier system, standards and regulations are taken into consideration. In the curriculum of the architecture, wood related courses are elective and theoretical courses. The content of courses is focused on wooden building material and the main source as trees. The study results show that information of wood and wood related issues are needed to be more involved in architectural education.
\end{abstract}

Keywords: Wooden material, wooden architectural heritage, architectural education, Istanbul 


\section{Giriş}

Ahşap, ilk barınaklardan gelişmiş tekniklerin uygulandığı günümüz yapılarına kadar yaygın olarak kullanılan doğal malzemedir. İşleme kolaylığı, ihtiyaca karşılık verebilir esnek yapısı ve doğal malzeme oluşu ahşabın yaygın olarak kullanımında etkendir. Teknolojik gelişmelerle birlikte ahşabın yapı malzemesi olarak özelliklerinin geliştirilmesi ve mimari tasarımda daha çok ön plana çıkmasını sağlamıştır. Güncel uygulama örnekleri 21. yüzyılda ahşabın yapı dünyasına yeni teknoloji ve yapısı daha da güçlendirilmiş olarak giriş yaptığını göstermektedir. 2018'in ilk aylarında Japonya'da bir ahşap firması 350 metre yüksekliğinde 70 katlı ahşap hibrid gökdeleni 2041 y1lında inşa edeceğini duyurmuştur (Şekil 1-a). Ahşap hibrid taşıyıcı sistemli 18 katlı öğrenci yurdu ise (Brock Commons Tall Wood House) Kanada Vancover'da 2017 yılında tamamlanarak kullanıma açılmıştır (Şekil 1-b). İngiltere Londra'da 2009'da ahşaptan inşa edilen 9 katlı konut/apartman (Murray Grove) ise gelişmiş teknoloji ile tasarlanarak uygulanmış ilk ahşap apartman örneği olarak gösterilmektedir (Şekil 1-c).

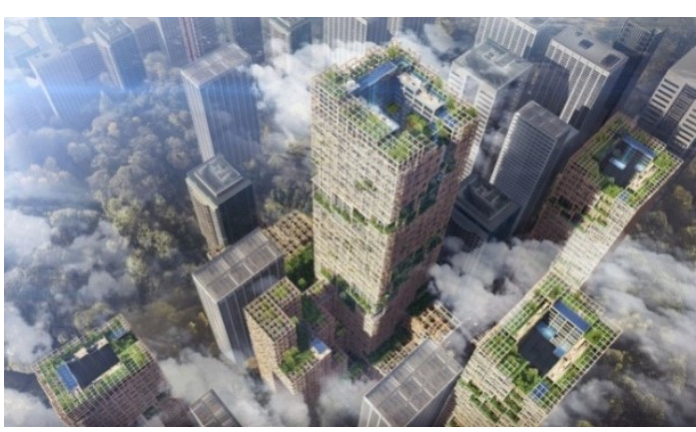

a)

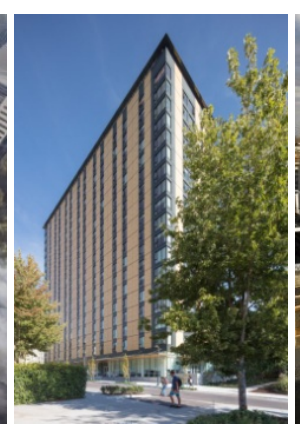

b)

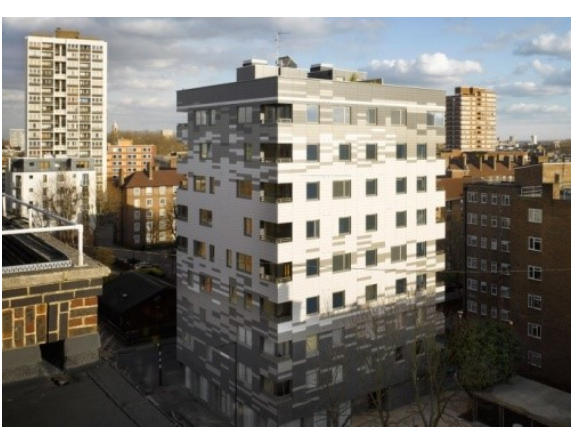

c)

Şekil 1 Çok katlı ahşap yapı örnekleri a) Japonya'da 2041'de inşa edilecek $350 \mathrm{~m}$ yüksekliğinde hibrid gökdelen (Sumitomo Forestry, 2018), b) Yurt Binas1, Kanada Vancover (Brock Commons Tallwood House (Acton Ostry Architects, 2018), c) Ahşap apartman, Murray Grove, 2009, Hackney, Londra, (Waugh Thistleton Architects , 2018).

Türkiye'nin birçok bölgesinde ahşabın kullanımı ve uygulama teknikleri, yapı bütününden yapı bileşenlerine kadar çeşitlilik içermektedir. Aynı zamanda konut, köprü, cami gibi farklı fonksiyon üstlenmiş tipolojilerde ve farklı ahşap kullanım teknikleri ile de zengin bir ahşap mimari mirastan söz etmek mümkündür. Konya Beyşehir Eşrefoğlu Camii (1299), Samsun Göğçeli Cami, Kastamonu Kasaba Köyü Mahmut Bey Cami, Afyonkarahisar Ulucami, Ordu İkizce ilçesi Laleli Camii (1560-1600) ahşabın kullanıldığı, yüzlerce yılı aşan tarihiyle önemli birkaç örnek olarak gösterilebilir (Şekil 2).

İstanbul'da, ahşap sivil mimarlık örnekleri açısından oldukça zengindir. İstanbul Boğaziçi'nde her iki kıyı boyunca sıralanmış yalılar ve gerisinde ahşap konutların yer aldığı yerleşimler, ahşap yapıların en seçkin örneklerini oluşturmaktadır. Köprülü Amcazade Hüseyin Paşa Yalısı (1699) 300 yılı aşan tarihiyle Boğaziçi Anadolu yakasının en eski yalısıdır (Eldem, 1933; Tamer, 1947). İstanbul Büyükada'da 20. yüzyılın başında Mimar Alexandre Vallaury tarafından otel olarak tasarlanmış ve yetimhane olarak kullanılmış olan ahşap yapı, dünyada döneminin ender örneklerden biri sayılmaktadır. Günay (2017)'a göre 20.Yüzyılın başında İstanbul'daki konutların \%95'i ahşaptır. Günay (2017), ahşabın 
kullanımında ülkelere göre farklılık oluşmasındaki nedenlerden iklim ve coğrafya gibi etkenlerin yanında en önemli nedenin yaşam biçimi ve gelenekler olduğunu belirtmektedir.

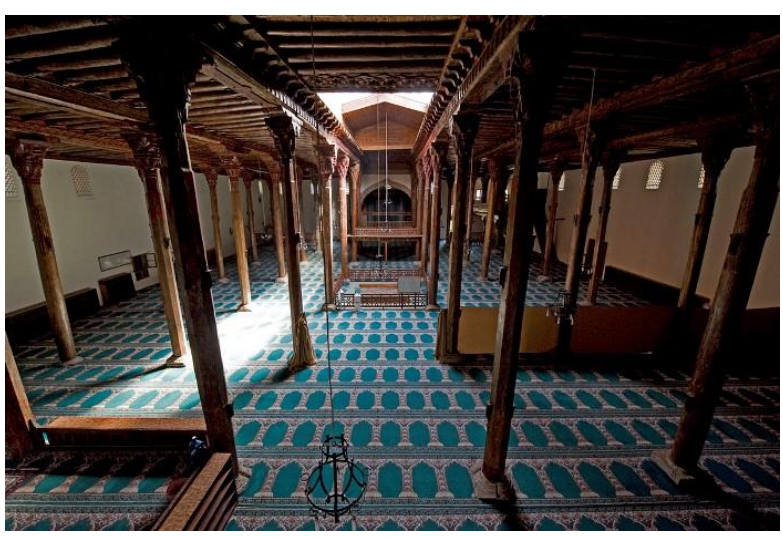

a)

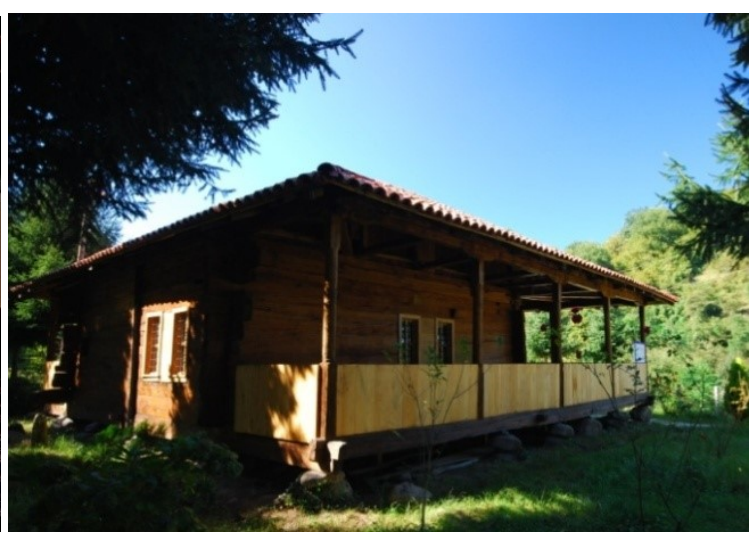

b)

Şekil 2 Ahşap mimarlık mirası cami örnekleri a) Konya Beyşehir Eşrefoğlu Camii, 1299 (Türkiye Kültür Portal1, 2018), b) Ordu İkizce İlçesi Laleli Camii, 1560-1600 (Ordu Kültür ve Turizm Müdürlüğü, 2018)

20. yüzyıl ilk çeyreğinden itibaren İstanbul'u belgeleyen önemli sigorta haritalarından olan Pervititich Haritaları'ndan da görülebildiği gibi İstanbul'da tarihi yarımada ve Boğaziçi'nin önemli kısmında ahşap yapım sistemli yap1 yoğunluğu oldukça yüksektir (Pervititch, 2000). Ancak diğer taraftan İstanbul'daki yangınlar ahşap yapılar için çok önemli bir tehdit oluşturmuş, mahallelerin yok olmasıyla sonuçlanmıştır (İstanbul Büyükşehir Belediyesi, 2018). Kuban'ın (1973) 70'li y1llarda işaret ettiği ahşap konut mimarisinin korunması sorunu, günümüzde azalmış ancak yine de korunabilecek yerleşim karakteristiği oluşturabilir düzeydeki ahşap mimarlık örnekler için de geçerli durumdadır (Kuban, 1973). Kuban'a göre ahşap sivil mimarlık örneklerinin korunmasında malzemenin yapısı, mülkiyet ve yeni sahip sorunu korumadaki önemli konulardır (Kuban, 1973). Mülkiyetin bölünmesi ve kullanımdaki müdahaleler yapıda önemli etki oluşturmaktadır. Uluslararası Anıtlar ve Sitler Konseyi (International Council on Monumentsand Sites, ICOMOS), Ahşap Mimari Mirasın Korunması İçin İlkeler Tüzüğü’nde, eğitim ve öğretim alt başlığında: “ahşap mimarlı̆̆ın tanınması, değerlerinin ve kültürel öneminin anlaşılmasını sağlayan eğitim programları" ile bu konuda bilinçlenmenin önemli bir parçası olduğu vurgulanmaktadır (ICOMOS, 2017). Bu çerçeveden bakıldığında ahşap mimari mirasın korunması ve aynı zamanda ahşap yapı malzemesinin mimarlık alanında kullanımında eğitimin önemli rol oynadığını söylemek mümkündür. Ahşap konusundaki eğitim malzeme, el sanatları, ustalık ve yapı alanındaki ekonomik değerinin devamlılığında da önemlidir. Mimarlık alanıyla bağlantılı olarak restorasyon alanındaki koruma odaklı eğitim ve çalışmalar için önemli olmakla beraber yeni tasarım çalışmalarında da ahşabın kullanımı gittikçe artmaktadır. Bu süreçte ahşap malzemenin mimarideki yeri ve kullanımındaki zenginliğin geleceğe aktarımında mimarlık ve ilgili eğitimlerin önemli görev üstlendiğini söylemek mümkündür (UAB, 2014). 


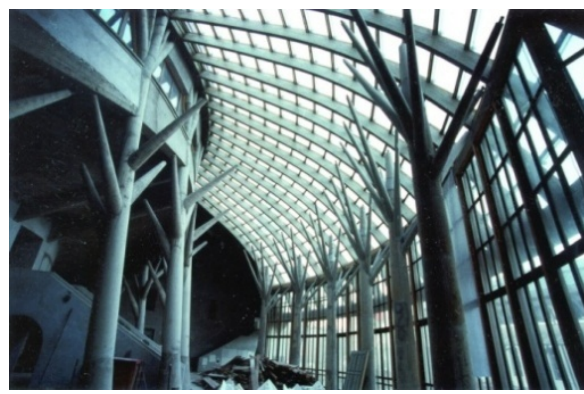

a)

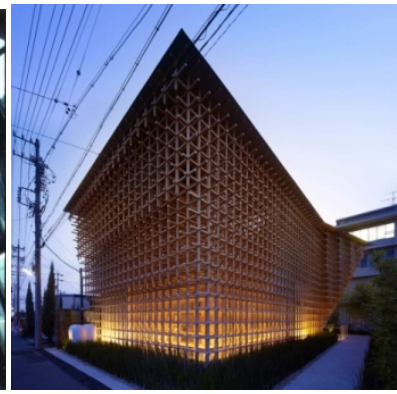

b)

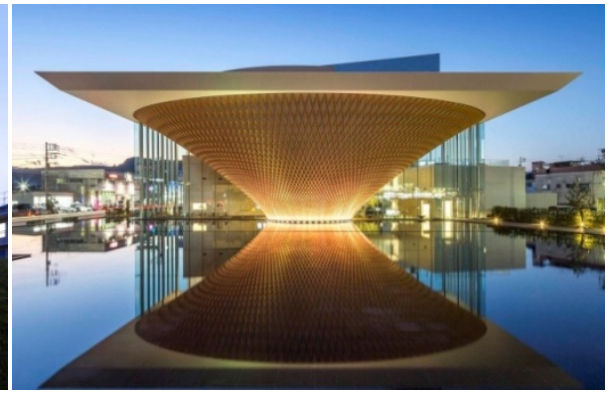

c)

Şekil 3 Ahşabın kullanıldığı çağdaş mimarlık örnekleri a)1995 Piliscsaba, Stefaneum, mimar Makovecz İmre (URL-1), b) GC Prostho Museum Research Center, Tokyo, mimar Kengo Kuma (URL-2), c) Mt.Fuji World Heritage Centre, 2017, mimar Shigeru Ban (URL-3)

Ahşap yapı malzemesi ile bütünleştirilmiş yapı tasarım örneklerine son yıllarda daha çok rastlanabilmektedir (Şekil 3). Ahşap kullanımını ön plana çıkaran yapı örneklerinin ahşabın görünürlüğünü arttırdığı söylenebilir. Türkiye'de zengin geleneksel ahşap mimari ile birlikte, yeni ahşap tasarım örnekleri farklı işlevlerde uygulamada yer bulmaktadır (Şekil 4).

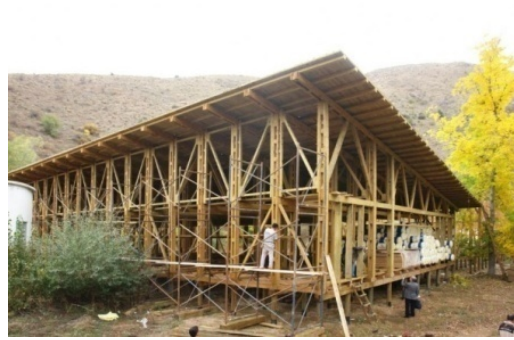

a)

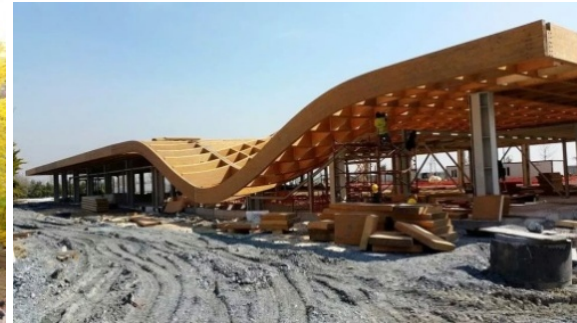

b)

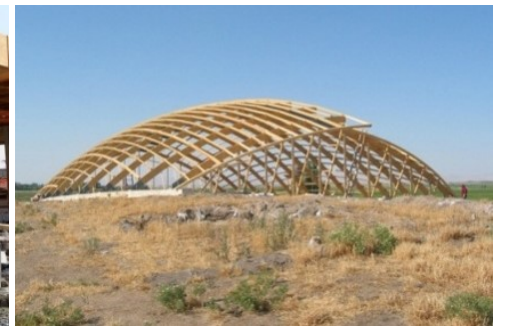

c)

Şekil 4 Ahşabın kullanıldığı çağdaş mimarlık örnekleri, Türkiye a) Gümüşhane Kültür Merkezi, 2008, mimar Nevzat Sayın (URL-4), b) İstanbul Büyükşehir Belediyesi İBB Avcılar Kültür Merkezi, 2017 (URL-5), c)Çatalhöyük Koruganı 2007, mimar Sinan Omacan (URL-6)

Ahşap, özellikle 1999 Marmara depreminden sonra deprem karşısındaki performansı nedeniyle yeniden gündeme gelmiş, konut, eğitim yapısı benzeri kullanım tercihinde artış gözlenmiştir. Deprem bölgeleri için taşınabilir okul yapıları tasarım ve uygulaması buna örneklerden biri gösterilebilir (ARKIV, 2018; Oran Mimarlık, 2018).

Ahşabın yapı malzemesi olarak özelliklerindeki gelişim, tasarımla bütünleştirilmesinde etkili olmuştur. Yapısal ahşap malzeme (Enginereed Wood Products, EWP) grubunda olan Çapraz Tabakalı Ahşap (CLT) ve Tutkallı Tabakalı Ahşap (Glulam) sistemler, taşıyıcı sistemde geniş olanaklar sağlamaktadır. Ahşabın elde edilmesi, üretimi, kullanımını ve geri dönüşümüne kadar birçok aşamada sürdürülebilir özellikte olması, yapıda kullanımında ön plana çıkmasında etkili olduğu düşünülebilir.

Türkiye'de ahşap yapılar konusunda TS 647, “Ahşap Yapıların Hesap ve Yapım Kuralları" standardı geçerlidir. Ahşap yapılar konusunda 2019' da yürürlüğe girecek "Türkiye Bina Deprem Yönetmeliği”ne “deprem etkisi altında ahşap bina taşıyıcı sistemlerin tasarımı için özel kurallar" kısmı eklenmiştir. Yönetmelikte ahşap ile ilgili konuların yer alması yeni 
yapılan ahşap yapılar açısından önemlidir. Eurocode 5 ise ahşap yapılar için yapım standartlarını belirleyen Avrupa standardı olmakla birlikte ülkemiz için de esas alınmaktadır.

Ahşap mimari mirasın başta Boğaziçi’nde olmak üzere birçok semtinde örneğinin yer aldığı İstanbul, mimarlık eğitimi ve ahşap kültürünü birleştirebileceği olanağ barındırmaktadır. Temel sorun ahşap mimari miras açısından zenginliğin, günümüze ve günümüz mimarisine nasıl yansıdığıdır. Yeni teknoloji ile geliştirilmiş ahşap malzemenin mimari uygulamalardaki kullanımı artmakla birlikte, ahşap ve ahşap mimari kültürün geçmiş ve bugün bağlantısının daha güçlendirilmesi gerektiği düşünülmektedir. Bütün bunlarla birlikte mimarlık eğitim programlarında ahşaba daha çok yer verilmesi, tasarım ve yapı malzemesi bütünlüğünün ahşap açısından daha derinlikli çalışılmasını sağlayabilir. Geleneksel yapı üretimindeki yerini bölgesel olanaklar çerçevesinde bulan ahşap, günümüz teknolojisiyle daha da güçlendirilmiş yapısı ile birlikte tasarımda daha fazla olanaklar sağlayabilmektedir.

Ahşap, mimarlık eğitimi boyunca yapı malzemesinden, taşıyıcı sistem tasarımına kadar derslerin içinde kısmen yer almaktadır. Ahşap malzeme ve/veya ahşap yapı özelinde bağımsız dersin bulunması, ahşap malzeme ve tasarım konusuna dikkatin daha çok çekilmesini sağlayabilir. Ulusal Ahşap Birliği'nin (UAB) raporunda (2014) yer aldığı gibi sadece mimarlık değil, inşaat mühendisliği eğitimi içinde daha çok yer alması önemlidir (Akça ve ark., 2018). Eğitim programlarında daha fazla yer alabilmesi, ahşap mimari mirasın korunmasına ilişkin çalışmalar ve yapı malzemesi olarak ahşabın tasarımda en uygun şekilde yer bulmasında olumlu etki edebileceği düşünülmektedir.

Ahşap, mimarlık eğitiminde özel bir program çerçevesinde dünyada birçok mimarlık okulunda yer bulmaktadır. Münih Teknik Üniversitesi, Mimarlık Bölümü, Mimari Tasarım içinde “Ahşap Konstrüksiyon ve Mimari Tasarım” kürsüsünde ahşap ve tasarımla ilişkili lisans seviyesinde eğitim programı bulunmaktadır (TUM, 2018). Almanya'da Rosenheim Uygulamalı Bilimler Üniversitesi Teknoloji Çalışmaları, ahşap, enerji ve yapım ana başlığında lisans seviyesinde ahşap binalar ve yapım, ahşap teknolojisi alanlarında bir dönemi uygulamalı olmak üzere yedi sömestrden oluşan mühendislik lisans eğitimi verilmektedir (Rosenheim University of Applied Sciences, 2018). Ahşap binalar ve yapım programında ders planı ahşap konstrüksiyon, statik, planlama ve üretim mühendisliği, yapı fiziği, yapı kimyası, malzeme bilimi, yapı teknolojisi, operasyon yönetimi ve planlama, şantiye yönetimi ve yap1 kanun ve yönetmelikleri kapsamında şekillenmektedir. İsviçre Bern Uygulamalı Bilimler Üniversitesi, Mimarlık, Ahşap ve İnşaat Mühendisliği altında Ahşap Mühendisliği alanında lisans ve yüksek lisans seviyesinde eğitim verilmektedir (Bern University of Applied Science, 2018). Lisans seviyesindeki eğitim şartları arasında ahşap sektöründe tamamlanmış mesleki eğitim ile meslek lisesi, ahşap sektöründe stajın tamamlandığı yüksek ortaokul veya ahşapla ilgili yüksek teknik okul mezunu olma bulunmaktadır. Bölümden mezuniyet dokuz ay süreli uygulamalı eğitim ve altı sömestr farklı konuların işlendiği derslerin tamamlanmasından (180'i derslerden olmak üzere toplam 210 Avrupa Kredi Transfer Sistemi, AKTS) oluşmaktadır. İlk yılda teknik bilgi, yasal ve ekonomik çecçeve ve malzeme bilgileri ile tanımlanmış dersleri takiben ikinci yıl için ahşap strüktür ve teknoloji veya süreç ve üretim 
yönetimi olarak iki ana daldan birinde eğitim derinleştirilmektedir. Üçüncü yıl ise yapım yönetimi, iç mimari yapımı, bina dış kabuğu, ahşap konut konstrüksiyonu ve ahşap yapım ve mühendislik alt dallarında ayrıntılı eğitim söz konusu olmaktadır. Genel olarak bakıldığında eğitimin ahşabın mühendislikle birleşen kısmıyla, strüktür, üretim ve üretim yönetimi ağırlıklı olduğunu söylemek mümkündür. Aalto Üniversitesi Sanat, Tasarım ve Mimarlık Okulu, Mimarlık Bölümünde Ahşap ve Ahşap Mimariyle ilgili bir y1llık yoğun programda ise ahşabın ekolojik, teknik ve mimari özellikleri araştırılmaktadır. Ahşap konusundaki eğitim, ağaçtan başlayarak deneysel bir yapı ile biten aşamaları içermektedir. Bir yılın sonunda yüksek lisans programına da aktarılabilir kredi (toplam 60 AKTS) ile sertifika sağlanmaktadır. Program, mimarlık alanında lisans derecesine sahip olan veya mühendislik, peyzaj mimarlığı veya iç mimari gibi ilgili alanlarda çalışan adaylara yöneliktir. Eşdeğer mesleki deneyime ve / veya üç yıl deneyime sahip olanlar da programa kayıt için çalışmaları ile birlikte değerlendirilebilmektedir (Aalto University, 2018). Söz konusu bir yıllık program ahşap konusunda uzmanlaşmayı hedefleyen, başvuru için ilgili alan deneyimi istenen lisans sonrası yüksek lisansa aktarılabilir kredili gruptadır.

Türkiye'de ahşap ve ahşap yapı sistemleri, lisans eğitimi öncesi lise seviyesinde de meslek eğitim programlarında yer almaktadır. Beş tanesi İstanbul'da olmak üzere Türkiye'nin birçok ilinde olmak üzere 38 Meslek ve Teknik Anadolu Lisesi’nde "İnşaat Teknolojisi" alanında "Ahşap Yapım Sistemleri” dalında lise seviyesinde eğitim bulunmaktadır (MEB, 2018). Devamında üniversitelerin teknoloji fakülteleri, ilgili bölümlerinde de eğitimi sürdürme olanağı bulunmaktadır. Buna yönelik hâlihazırda iki program bulunmaktadır. Muğla S1tkı Koçman Üniversitesi ve Ankara Gazi Üniversitesi Teknoloji Fakültesi, Ağaç İşleri Endüstri Mühendisliği Bölümleri'nde ağırlıklı olarak malzeme yapısı, işleme, üretim ve mobilya tasarım ve üretimi kapsamında lisans seviyesinde eğitim verilmektedir. Geleneksel ve günümüz ahşap yapı ve yapım sistemlerine ilişkin seçmeli derslerle bölüm ders programı tamamlanmaktadır. Lisans eğitimi dışında ahşabı konu alan İstanbul Büyükşehir Belediyesi (IBB) Koruma Uygulama ve Denetim Müdürlüğü (KUDEB) tarafindan düzenlenen "Geleneksel Ahşap Yapılarda Koruma ve Onarım Eğitim Programı" ise Restorasyon Meslek Yüksekokulu Mimari Restorasyon Bölümü mezunlarının katılabileceği dört aylık kurs programı bulunmaktadır.

Mimarlık eğitiminde ahşap, kültür varlıkları koruma kapsamında ahşap mimarlık mirası, yapı malzemesi bilgisi ve kısmen tasarım atölyelerinde tasarımın bir parçası olarak yer almaktadır. Ahşabın özellikleri, üretim süreci ve kullanımı dolayısıyla birçok alanla teması da beraberinde getirmektedir. Mimarlık eğitiminin temel eksenini oluşturan tasarım atölyelerinde, farklı bina programlarının geliştirilmesi sürecinde strüktürden yapı dış kabuğuna birçok bileşende uygun yapı malzemesi seçimi, paralelindeki ilgili birçok dersle desteklenmektedir. Bu nedenle yapılı fiziksel çevreyle ilişkili olarak tasarım alanında ahşap yapı malzemesinin ve ahşabın ne şekilde yer bulduğunun mimarlık lisans eğitiminden izlenebileceğini söylemek mümkündür. Bu kapsamda çalışmada mimarlık eğitiminde ahşap ve ahşap yapılar konusunda bağımsız ders araştırması yapılmıştır. Mimarlık bölümleri lisans seviyesinde yapılan söz konusu araştırmada mevcut durum, ahşabın mimarlık eğitiminde yer alma biçiminin değerlendirilmesi amacıyla gerçekleştirilmiştir. 


\section{Materyal ve Metot}

\subsection{Materyal}

Çalışmada, İstanbul adresli üniversiteler sınırlılığında, ahşap ve ahşap yapılar konusunda bağımsız olarak hazırlanmış ders araştırması kapsamında mimarlık bölümleri müfredat incelemesi gerçekleştirilmiştir. Üniversitelerin kontenjan bilgileri için 01 Ağustos 2018 tarihli ÖSYM kontenjan dokümanındaki bilgiler esas alınmıştır (ÖSYM, 2018). Mimarlık Bölümü ders içerik araştırması ise üniversitelerin resmi internet sayfalarından bilgi alınmak suretiyle, Ağustos 2018 tarihinde gerçekleştirilmiştir.

\subsection{Metot}

Çalışmada mimarlık Türkiye genelinde ve İstanbul özelinde güncel mimarlık okul sayı ve kontenjanları incelenmiştir (ÖSYM, 2018). İstanbul'daki mimarlık okulları müfredatında bulunan ahşap dersler ayrıntılı ele alınmıştır. Müfredat incelemesi, İstanbul'da kurulu üniversitelerin resmi internet sitelerinden gerçekleştirilmiştir. Araştırmada temel soru, zengin ahşap mimarlık mirası barındıran Türkiye'de mimarlık eğitiminde ahşap yeterince yer buluyor mu? Eğer yer buluyor ise hangi konular kapsamında ağırlıklı yer almaktadır? İstanbul hem ahşap mimari hem de mimarlık eğitimi açısından önemli bir merkezdir. Bu sorulara yanıtı İstanbul merkezli okullar çerçevesinde aranmaya çalışılmıştır.

Mimarlık bölümü lisans düzeyinde ders içerik araştırmasında ahşap konusunda bağımsız ders varlığı araştırması; bulunduğu yarıyıl, ders kategorisi (seçmeli/zorunlu) yerel kredisi, Avrupa Kredi Transfer Sistemi (AKTS), ders süresi, uygulama, teorik ve laboratuar bilgisi ve ders içeriği incelenmiştir. Derslerin içerik incelemesinde, İstanbul' da ve mimarlık bölümü bulunan 34 üniversite içinde bir üniversitenin (Şehir Üniversitesi) ders planına ulaşılamamıştır. İstanbul adresli on bir mimarlık bölümü ders planında yer alan ahşap konulu ders örnekleri ayrıntılı incelenmiştir. Ders içerik incelemesinde ders kapsamında ele alınan konular, yapı malzemesi ahşap ve ana maddesi ağaçların yapısal özellikleri, ahşabın yapıda kullanım alanları, ahşap mimari miras, taşıyıcı sistem, standart ve yönetmelikler şeklinde gruplandırılmıştır.

\section{Bulgular ve Tartışma}

\section{1 Üniversiteler ve mimarlık bölümleri}

Türkiye'de özel üniversitelerle birlikte toplam 206 üniversite bulunmaktadır (YÖK, 2018). Bu sayı diğer ülkelerdekilerle birlikte (Kuzey Kıbrıs Türk Cumhuriyeti, Azerbaycan, Kazakistan, Kırgızistan, Makedonya, Bosna-Hersek, Moldova) toplam 215'e ulaşmaktadır (ÖSYM, 2018). Söz konusu üniversitelerin yaklaşık yarısında, toplam 108 üniversitede (51'i devlet üniversitesinde) mimarlık eğitimi verilmektedir (ÖSYM, 2018). Türkiye genelinde 2018-2019 öğretim dönemi için Mimarlık Programına (Türkçe ve İngilizce) yaklaşık dokuz bin (Okul birincisi kontenjanı da dâhil olmak üzere kontenjan toplamı 8786) kontenjan ayrılmıştır. İstanbul'da yer alan üniversitelerin içinde mimarlık bölüm sayısı ise dördü devlet üniversitesi olmak üzere toplam 34'tür. Türkiye genelindeki mimarlık bölümü kontenjanının yüzde 39'u (3402 kontenjan) İstanbul'dadır. İstanbul, bölüm sayısı ve ayrılan kontenjan açısından mimarlık eğitiminde önemli konumdadır. Türkiye genelinde üniversitelerden 
38'inde mimarlık için İngilizce dilinde eğitim olanağı bulunmaktadır. Bunlardan 18'i İstanbul'dadır. Genel olarak bakıldığında üniversite sayısı, kontenjan ve öğretim üyesi açısından İstanbul'un mimarlık eğitiminde önemli bir merkez olduğunu söylemek mümkündür.

\section{2 İstanbul'da bulunan Mimarlık Bölümleri ve Bağımsız Ahşap Dersleri}

Üniversitelerin mimarlık bölümü ders planlarında lisans düzeyinde yer alan ahşap ile ilgili bağımsız derslerin içerikleri üniversitelerin resmi internet sitelerinden ulaşılmıştır. Araştırmada İstanbul'da mimarlık bölümü bulunan 34 üniversite içinde 11 mimarlık bölümünde ahşap ile ilgili bağımsız dersin ders planında yer aldığı görülmüştür. İçeriklerin değerlendirilmesinde yapı malzemesi ahşap ve ana maddesi ağaçların yapısal özellikleri, ahşabın yapıda kullanım alanları, ahşap mimari miras, taşıyıcı sistem, standart ve yönetmelikler, tasarım ve uygulama ana başlıkları dikkate alınmıştır. Ahşap derslerine ilişkin ayrıntılar üniversite ölçeğinde Çizelge 1-11'de gösterilmiştir. Çizelgedeki bilgiler ders kataloglarından olduğu gibi aktarılmıştır.

Çizelge 1. Doğuş Üniversitesi Mimarlık Bölümü, “Ahşap Yapılar” dersi (Doğuş Üniversitesi, 2018)

\begin{tabular}{|c|c|c|c|c|c|c|c|c|}
\hline $\begin{array}{l}\text { Üniversite } \\
\text { Adı }\end{array}$ & $\begin{array}{l}\text { Ders } \\
\text { Kodu }\end{array}$ & Ders Adı & Teori & Uygulama & Kredi & AKTS & Yarıyıl & $\begin{array}{l}\text { Ders } \\
\text { Türü }\end{array}$ \\
\hline $\begin{array}{c}\text { Doğuş } \\
\text { Üniversitesi }\end{array}$ & $\begin{array}{l}\text { MİMA23 } \\
5\end{array}$ & Ahşap Yapılar & 3 & 0 & 3 & 5 & $\begin{array}{c}4,5 \\
6,8\end{array}$ & $\begin{array}{l}\text { Bölüm } \\
\text { Seçmeli }\end{array}$ \\
\hline Ders İçe & \multicolumn{8}{|c|}{$\begin{array}{l}\text { Ağaç malzeme, yıllardır konstrüksiyon malzemesi olarak kullanılması ve tüm yapılar içinde } \\
\text { en iyi çevresel ve yenilenebilir malzeme olması, yapıdaki kullanım yeri ile ağaç malzeme } \\
\text { ilişkisi, ağaç malzeme ile ilgili bazı önemli özellikler, ağaç malzemenin korunması, kurutma, } \\
\text { buharlama, emprenye ve yüzey işlemleri, ahşap kökenli yapı elemanları ve malzemeler, } \\
\text { yapılarda kullanım yönünden ağaç malzemenin fiziksel, mekanik ve teknolojik özelliklerinin } \\
\text { irdelenmesi, ahşabın yapıda kullanım olanakları, ahşap yapı sistemleri, yığma, karkas, lamine } \\
\text { sistemler. }\end{array}$} \\
\hline
\end{tabular}

Doğuş Üniversitesi Mimarlık Bölüm müfredatında yer alan “Ahşap Yapılar” dersi 4. yarıyıldan itibaren seçilebilen, üç saatlik teorik olarak kurgulanmış bölüm seçmeli ders grubundadır (Çizelge 1). Ders içeriğini ahşabın malzeme özellikleri, koruma, işleme teknikleri, yapıda kullanım olanakları, yapı sistemleri oluşturmaktadır. Ders içeriğinden, yapı malzemesi olarak ahşabın özelliklerine odaklandığı ve bu kapsamda yapıda kullanım alanlarının irdelendiği söylenebilir.

Çizelge 2. Fatih Sultan Mehmet Üniversitesi, Mimarlık Bölümü, "Mimaride Ahşap Kullanımı" dersi (Fatih Sultan Mehmet Üniversitesi, 2018)

\begin{tabular}{|c|c|c|c|c|c|c|c|c|}
\hline $\begin{array}{c}\text { Üniversite } \\
\text { Adı }\end{array}$ & $\begin{array}{c}\text { Ders } \\
\text { Kodu }\end{array}$ & Ders Adı & Teori & Uygulama & Kredi & AKTS & Yarıyıl & $\begin{array}{c}\text { Ders } \\
\text { Türü }\end{array}$ \\
\hline $\begin{array}{c}\text { Fatih Sultan } \\
\text { Mehmet } \\
\text { Üniversitesi }\end{array}$ & MiM014 & $\begin{array}{c}\text { Mimaride Ahşap } \\
\text { Kullanımı }\end{array}$ & 2 & 0 & & 4 & 3,4 & Seçmeli \\
\hline Ders İçeriği & \multicolumn{2}{|c|}{$\begin{array}{l}\text { Ahşabın Nitelikleri/ Ahşap Yapı Ürünleri/ Türkiye' de Geleneksel Ahşap Yapı Üretimi, } \\
\text { Taşıııı Sistem Sınıflandırması, Yöresel Yapım Yöntemleri/ Dünya' da Ahşap Yapı Üretimi, } \\
\text { Yapım Yöntemleri// Türkiye' de Günümüzde Ahşap Yapı Üretimi. }\end{array}$} \\
\end{tabular}


Fatih Sultan Mehmet Üniversitesi, Mimarlık Bölümü'nde "Mimaride Ahşap Kullanımı" adıyla seçmeli ders kapsamında yer alan ders iki saatlik teorik temelli ve ikinci sınıfta alınabilmektedir (Çizelge 2). Ders içeriğinde, ahşap birleşimi, ilgili standart ve yönetmelikler dışında taşıyıcı sistemden Dünya'da ahşap yapı üretimine kadar birçok konunun yer aldığı gözlenmiştir.

Çizelge 3. Haliç Üniversitesi Mimarlık Bölümü, Ahşap Strüktürlerin Tasarım İlkeleri dersi (Haliç Üniversitesi, 2018)

\begin{tabular}{|c|c|c|c|c|c|c|c|c|}
\hline $\begin{array}{c}\text { Üniversite } \\
\text { Adı }\end{array}$ & $\begin{array}{l}\text { Ders } \\
\text { Kodu }\end{array}$ & Ders Adı & Teori & Uygulama & Kredi & AKTS & Yarıyl & $\begin{array}{l}\text { Ders } \\
\text { Türü }\end{array}$ \\
\hline $\begin{array}{l}\text { Haliç } \\
\text { Üniversitesi }\end{array}$ & MїM264 & $\begin{array}{c}\text { Ahşap } \\
\text { Strüktürlerin } \\
\text { Tasarım İlkeleri }\end{array}$ & 2 & 0 & 4 & 4 & 4 & $\begin{array}{c}\text { Alan } \\
\text { Seçmeli }\end{array}$ \\
\hline Ders İçc & \multicolumn{8}{|c|}{$\begin{array}{l}\text { Ahşap malzemenin tanıtılması, Ahşabın yapıda kullanılması, Ahşap birleşim araçları, Ahşap } \\
\text { yapılarda bağlantılar, Ahşap yapılarda taşıyıı sistemlerin incelenmesi, ahşap yığma } \\
\text { sistemler ve örnekleri, Ahşap karkas (iskelet) sistemler ve ahşap karkas sistemlerde taşıyıc1 } \\
\text { sistem elemanları, Tutkallı tabakalı ahşap elemanlarla oluşturulan sistemler (lamine ahşap } \\
\text { sistemler) ve örnekleri, Ahşap panel sistemler ve örnekleri; Ahşap yapılara ilişkin Türkiye'de } \\
\text { mevcut kanun, yönetmelik ve standartlar, Literatürde yer alan ahşap yap1 örneklerinin } \\
\text { incelenmesi. }\end{array}$} \\
\hline
\end{tabular}

Haliç Üniversitesi Mimarlık Bölümü ders planında alan seçmeli olarak tanımlanan ve iki saatlik teorik ders ikinci sınıfta alınabilmektedir (Çizelge 3). "Ahşap Strüktürlerin Tasarım İlkeleri" adlı ders, ahşabın malzeme olarak özellikleriyle birlikte ahşabın taşıyıcı sistemde bulunuşu ve ayrıntılarına odaklanmaktadır. Ders içeriğinde, ahşap yapılara ilişkin Türkiye'deki mevzuatın yer aldığ 1 gözlenmiştir. A ğırlıklı taşıyıcı sistem konularının yer aldığı ders, yapısal ahşap ürünleri bilgisini de içermektedir.

Çizelge 4. İstanbul Gelişim Üniversitesi Mimarlık Bölümü, “Ahşap Yapılar” dersi (İstanbul Gelişim Üniversitesi, 2018)

\begin{tabular}{|c|c|c|c|c|c|c|c|c|}
\hline $\begin{array}{c}\text { Üniversite } \\
\text { Adı }\end{array}$ & $\begin{array}{c}\text { Ders } \\
\text { Kodu }\end{array}$ & Ders Adı & Teori & Uygulama & Kredi & AKTS & Yarıyıl & $\begin{array}{c}\text { Ders } \\
\text { Türü }\end{array}$ \\
\hline $\begin{array}{c}\text { İstanbul } \\
\text { Gelişim } \\
\text { Universitesi }\end{array}$ & TSD446 & Ahşap Yapılar & 2 & 0 & 2 & 5 & 8 & $\begin{array}{c}\text { Seçmeli } \\
\text { Ders }\end{array}$ \\
\hline Ders İçeriği & $\begin{array}{l}\text { Ahşap özelikleri, geleneksel ahşap yapılar, endüstriyel ahşap yapı ürünleri. Modern ahşap } \\
\text { yapılar: hafif ahşap sistemler, tutkallı tabakalı masif ahşap sistemler, çapraz tabakalı lamine } \\
\text { masif ahşap sistemler. Bileşim elemanları. Kullanım alanları: mobilya, kaplama, kalıp } \\
\text { sistemleri. Yönetmelik ve standartlar } \\
\text { *Araştırma tarihinde seçmeli ders olarak görünen ders, yenilenerek 2018-2019 Öğgretim Yılı } \\
\text { Ders planında zorunlu ders olarak görünmektedir. }\end{array}$ \\
\hline
\end{tabular}

İstanbul Gelişim Üniversitesi Mimarlık Bölümü ders planında “Ahşap Yapılar” dersi sekizinci yarıyılda seçmeli ders kapsamındadır. Söz konusu ders 2018-2019 Öğretim Yılı Ders planında üçüncü sınıf altıncı yarıyılda MIM328 ders kodu ile “Ahşap Yapılar” olarak zorunlu ders kapsamına alınmıştır. Değişiklik inceleme tarihinden sonra söz konusudur. $\mathrm{Bu}$ nedenle seçmeli ders içeriği incelenmiştir. Söz konusu ders iki saatlik teorik kapsamda olup, içeriğini ahşap malzeme özellikleriyle birlikte geleneksel ahşap yapılar, endüstriyel ahşap 
yapı ürünleri, ahşap yapım sistemleri, ahşabın kullanım alanları, birleşim elemanları ve ilgili mevzuat oluşturmaktadır.

Çizelge 5. İstanbul Kültür Üniversitesi Mimarlık Bölümü, “Ahşap Yapım Sistemleri” dersi (İstanbul Kültür Üniversitesi, 2018)

\begin{tabular}{|c|c|c|c|c|c|c|c|c|}
\hline $\begin{array}{c}\text { Üniversite } \\
\text { Adı }\end{array}$ & $\begin{array}{c}\text { Ders } \\
\text { Kodu }\end{array}$ & Ders Adı & Teori & Uygulama & Kredi & AKTS & Yarıyıl & $\begin{array}{l}\text { Ders } \\
\text { Türü } \\
\end{array}$ \\
\hline $\begin{array}{c}\text { İstanbul } \\
\text { Kültür } \\
\text { Üniversitesi }\end{array}$ & $\begin{array}{c}\text { MIM020 } \\
9\end{array}$ & $\begin{array}{l}\text { Ahşap Yapım } \\
\text { Sistemleri }\end{array}$ & 3 & 0 & - & 4 & $\begin{array}{c}3,4,5,6 \\
7,8\end{array}$ & Seçmeli \\
\hline Ders İçeriği & \multicolumn{8}{|c|}{$\begin{array}{l}\text { Ahşap malzemenin tanıtılması, Ahşabın yapıda kullanılmass, Ahşap birleşim araçları, Ahşap } \\
\text { yapılarda bağlantılar, Ahşap yapılarda taşıyı sistemlerin incelenmesi, ahşap yığma } \\
\text { sistemler ve örnekleri, Ahşap karkas (iskelet) sistemler ve ahşap karkas sistemlerde taşıyıcı } \\
\text { sistem elemanları, Ahşap karkas (iskelet) sistemler ve ahşap karkas sistemlerde taşıyı1 } 1 \\
\text { sistem elemanları, Tutkallı tabakalı ahşap elemanlarla oluşturulan sistemler (lamine ahşap } \\
\text { sistemler) ve örnekleri, Ahşap panel sistemler ve örnekleri; Ahşap yapılara ilişkin Türkiye'de } \\
\text { mevcut kanun, yönetmelik ve standartlar, Literatürde yer alan ahşap yapı örneklerinin } \\
\text { incelenmesi. }\end{array}$} \\
\hline
\end{tabular}

İstanbul Kültür Üniversitesi Mimarlık Bölümü ders planında yer alan “Ahşap Yapım Sistemleri” dersi ikinci sınıftan itibaren alınabilir seçmeli ders olarak düzenlenmiştir (Çizelge 5). Üç saatlik teorik ders olarak kurgulanan ders içeriğini, ahşap malzeme özellikleri, taşıyıcı sistem yapıs1, yapısal ahşap ürünler, mevcut mevzuat bilgisi ve mevcut ahşap yapı örneklerinin incelenmesi oluşturmaktadır.

Medipol Üniversitesi Mimarlık Bölümü ders planında yer alan “Ahşap Yapı Uygulamaları" adlı ders diğer üniversitelerden farklı olarak bir saat teorik ve iki saat uygulamadan oluşmaktadır. Programa bağlı seçmeli ders sınıfındadır. İkinci sınıfta alınabilmektedir (Çizelge 6). Ders Ahşap malzeme özellikleri, işleme ve koruma, ağaç çeşitleri, geleneksel mimaride ahşap yapı elemanları, taşıyıcı sistem, yapıda kullanım alanlarına odaklanmaktadır.

Çizelge 6. Medipol Üniversitesi Mimarlık Bölümü, “Ahşap Yapı Uygulamaları” dersi (Medipol Üniversitesi, 2018)

\begin{tabular}{|c|c|c|c|c|c|c|c|c|}
\hline $\begin{array}{c}\text { Üniversite } \\
\text { Adı }\end{array}$ & $\begin{array}{c}\text { Ders } \\
\text { Kodu }\end{array}$ & Ders Adı & Teori & Uygulama & Kredi & AKTS & Yarıyl & $\begin{array}{c}\text { Ders } \\
\text { Türü }\end{array}$ \\
\hline $\begin{array}{c}\text { Medipol } \\
\text { Unniversitesi }\end{array}$ & $\begin{array}{c}\text { MIM214 } \\
839\end{array}$ & $\begin{array}{c}\text { Ahşap Yapı } \\
\text { Uygulamaları }\end{array}$ & 1 & 2 & 2 & 3 & 3 & $\begin{array}{c}\text { Programa } \\
\text { Bağlı } \\
\text { Seçmeli }\end{array}$ \\
\hline Ders İçeriği & $\begin{array}{l}\text { Ahşap Malzemenin tanımı. Ahşap-Su ilişkisi, kurutma, korunması. Ağaç çeşitleri (iğne ve } \\
\text { Geniş yaprakl1). Geleneksel Mimaride Ahşap Yapı elemanları. Taşıyıı sistem elemanları. } \\
\text { Ahşap Karkas. Tavanlar ve Döşsemeler. Duvarlar. Çatı Elemanları. Ahşap Kapılar,Ahşap } \\
\text { Pencereler,Ahşap Merdivenler,Ahşap Birleştirmeler. }\end{array}$ \\
\end{tabular}

Sabahattin Zaim Üniversitesi Mimarlık Bölümü ders planında yer alan “Ahşap ve Çelik Yapılar" adlı derste altıncı yarıyıldan itibaren çelik malzeme ile birlikte ahşap malzeme ile taşıyıcı sistem tasarımı ele alınmaktadır (Çizelge 7). Taşıyıcı sistem elemanlarının tasarımına yönelik konular ağırlıklı olduğu gözlenmiştir. İkinci diğer bağımsız ders içeriğinde ise ahşap 
malzeme özellikleri ile birlikte proje ve model çalışması da yer almaktadır. Her iki ders aynı şekilde iki saatlik teorik olarak düzenlenmiştir. Üçüncü sınıfta birbirini takip eden iki ders öncelikle taşıyıcı sistem çözümü ve diğer derste ise geleneksel ahşap yapılardan yapısal ahşap ürünleri yer almaktadır. Ahşap yapı malzemesinin taşıyıı sistemde yer bulması ve farklı bir yapı malzemesi çelik ile birlikte değerlendirilmesi bakımından diğer okullarda bulunan ahşap konulu derslerden ayrılmaktadir.

Çizelge 7. Sabahattin Zaim Üniversitesi Mimarlık Bölümü, “Ahşap ve Çelik Yapılar” ve "Ahşap Yapılar” dersleri (İstanbul Sabahattin Zaim Üniversitesi, 2018)

\begin{tabular}{|c|c|c|c|c|c|c|c|c|}
\hline $\begin{array}{c}\text { Üniversite } \\
\text { Adı }\end{array}$ & $\begin{array}{l}\text { Ders } \\
\text { Kodu }\end{array}$ & Ders Adı & Teori & Uygulama & Kredi & AKTS & Yarıyıl & $\begin{array}{l}\text { Ders } \\
\text { Türü }\end{array}$ \\
\hline $\begin{array}{l}\text { Sabahattin } \\
\text { Zaim } \\
\text { Üniversitesi }\end{array}$ & MIM 336 & $\begin{array}{c}\text { Ahşap ve Çelik } \\
\text { Yapılar }\end{array}$ & 2 & 0 & 2 & 3 & 6 & $\begin{array}{l}\text { Bölüm } \\
\text { Seçmeli }\end{array}$ \\
\hline Ders İçeriği & \multicolumn{8}{|c|}{$\begin{array}{l}\text { Ahşap ve Çelik yapı tasarımı ve malzeme özellikleri anlatılır. Ahşabın sınıflandırılması ve } \\
\text { mekanik özellikleri. Ahşap yapı elemanlarının tasarımında kullanılan yönetmelikler. Ahşap } \\
\text { yapı elemanlarının birleşimlerinin tasarımı. Çekmeye çalışan ahşap yapı elemanlarının } \\
\text { tasarımı. Basınca çalışan ahşap yapı elemanlarının tasarımı. Ahşap kafes kirişlerin tasarımı. } \\
\text { Eğilmeye çalışan ahşap yapı elemanlarının tasarımı. Çok katlı yapılarda birleşimler. Çok katlı } \\
\text { çelik yapılarda döşeme sistemleri. Çok katlı yapılarda yangın problemi. Çok katlı yapılarda } \\
\text { uygulama örnekleri tartışması. Çok katlı yapılarda uygulama örnekleri tartışması. }\end{array}$} \\
\hline & MIM 425 & Ahşap Yapılar & 2 & 0 & 2 & 3 & 7 & $\begin{array}{l}\text { Bölüm } \\
\text { Seçmeli }\end{array}$ \\
\hline Ders İçeriği & \multicolumn{8}{|c|}{$\begin{array}{l}\text { Ahşap malzemenin özellikleri, Türkiye'de geleneksel ahşap yapılar, günümüz teknolojisi ile } \\
\text { üretilen ahşap yapıların sistem analizleri, yapım yöntemleri ve uygulama örnekleri. Ağacın } \\
\text { yapısı, sınıflandırmalar, özellikler, ahşaba zarar veren etkenler, kurutma ve koruma, kereste } \\
\text { üretimi, ahşap levha üretimi, hazır ahşap ürünler, yapıda kullanım. Türkiye'de geleneksel } \\
\text { ahşap yapılar; sistem kurguları, yapım yöntemleri. Ahşap kütük yapılar; sistem kurgusu, yapım } \\
\text { yöntemleri, ahşap panel yapılar; sistem kurgusu, yapım yöntemleri. Kaburgalı ahşap çerçeve } \\
\text { yapılar; sistem kurgusu, yapım yöntemleri. Tabakalı ahşap elemanlar; üretim yöntemi, formlar. } \\
\text { Büyük açıklıklı ahşap yapılar; sistem kurguları, uygulama yöntemleri. Proje ve model } \\
\text { çalışması. }\end{array}$} \\
\hline
\end{tabular}

İstanbul Ticaret Üniversitesi Mimarlık Bölümü ders planında yer alan "Mimaride Ahşap Kullanımı" adlı ders genel bilgilerine ulaşılmış olmakla birlikte içeriğine ulaşılamamıştır. $\mathrm{Bu}$ nedenle içerik değerlendirmesi yapılamamıştır (Çizelge 8). Ders üç saatlik teorik kapsamda olup dördüncü sınıf seçmeli dersleri içinde planlanmıştır.

Çizelge 8. İstanbul Ticaret Üniversitesi Mimarlık Bölümü, "Mimaride Ahşap Kullanımı" dersi (İstanbul Ticaret Üniversitesi, 2018)

\begin{tabular}{|c|c|c|c|c|c|c|c|c|}
\hline $\begin{array}{c}\text { Üniversite } \\
\text { Adı }\end{array}$ & $\begin{array}{c}\text { Ders } \\
\text { Kodu }\end{array}$ & Ders Adı & Teori & Uygulama & Kredi & AKTS & Yarıyıl & $\begin{array}{c}\text { Ders } \\
\text { Türü }\end{array}$ \\
\hline $\begin{array}{c}\text { İstanbul } \\
\text { Ticaret } \\
\text { Unniversitesi }\end{array}$ & MIM 440 & $\begin{array}{c}\text { Mimaride Ahşap } \\
\text { Kullanımı }\end{array}$ & 3 & 0 & 3 & 5 & 8 & Seçmeli \\
\hline Ders İçeriği & $* * *$ Ders içeriğine ulaşılamamıştır. \\
\hline
\end{tabular}


Çizelge 9. Mimar Sinan Güzel Sanatlar Üniversitesi Mimarlık Bölümü, "Ahşap Yapım Sistemleri” ve "İleri Teknolojili Ahşap Yapım Sistemleri” dersleri (Mimar Sinan Güzel Sanatlar Üniversitesi, 2018)

\begin{tabular}{|c|c|c|c|c|c|c|c|c|}
\hline $\begin{array}{l}\text { Üniversite } \\
\text { Adı }\end{array}$ & $\begin{array}{l}\text { Ders } \\
\text { Kodu }\end{array}$ & Ders Adı & Teori & Uygulama & Kredi & AKTS & Yarıyıl & $\begin{array}{l}\text { Ders } \\
\text { Türü }\end{array}$ \\
\hline $\begin{array}{l}\text { Mimar Sinan } \\
\text { Güzel Sanatlar }\end{array}$ & $\begin{array}{l}\text { Mim } \\
231\end{array}$ & $\begin{array}{l}\text { Ahşap Yapım } \\
\text { Sistemleri }\end{array}$ & 2 & 0 & - & 3 & 3 & Seçmeli \\
\hline Ders İçeriği & \multicolumn{8}{|c|}{$\begin{array}{l}\text { Ahşap yapım sistemlerinin sistematik olarak açıklanması, temel konuların ve detayların } \\
\text { çözümü ile ilgili bilgilerin aktarılması ve bölgelere göre dağılımın açılanması. Ahşap yapı } \\
\text { sistemleriyle ilgili teknik bilgilerin verilmesi ve strüktür sistemlerinin sınıflandırılmasına } \\
\text { dayanan teorik öğreti. }\end{array}$} \\
\hline & $\begin{array}{l}\text { Mim } \\
230\end{array}$ & $\begin{array}{l}\text { İleri Teknolojili } \\
\text { Ahşap Yapım } \\
\text { Sistemleri }\end{array}$ & 2 & 0 & - & 3 & 4 & Seçmeli \\
\hline Ders İçeriği & \\
\hline
\end{tabular}

Mimar Sinan Güzel Sanatlar Üniversitesi Mimarlık Bölümü ders planında ahşap konusunda iki bağımsız ders bulunmaktadır (Çizelge 9). Her iki ders de ikinci sınıfta seçmeli ders statüsünde ve iki saatlik teorik ders olarak tanımlıdır. Ahşap Yapım Sistemleri adlı ders içeriği taşıyıcı sistem ağırlıklıdır. İleri Teknolojili Ahşap Yapım Sistemleri adlı diğer ders içeriğini ise konuyla ilgili temel bilgi ve uygulama ilkeleri oluşturmaktadır.

Çizelge 10. Yıldız Teknik Üniversitesi Mimarlık Bölümü, "Ahşabın Yapılarda Kullanımı” dersi (Yıldız Teknik Üniversitesi , 2018)

\begin{tabular}{|c|l|c|c|c|c|c|c|c|}
\hline $\begin{array}{l}\text { Üniversite } \\
\text { Adı }\end{array}$ & $\begin{array}{l}\text { Ders } \\
\text { Kodu }\end{array}$ & Ders Adı & Teori & Uygulama & $\begin{array}{l}\text { Kred } \\
\text { i }\end{array}$ & $\begin{array}{l}\text { AKT } \\
\text { S }\end{array}$ & Yarıyıl & $\begin{array}{l}\text { Ders } \\
\text { Türü }\end{array}$ \\
\hline $\begin{array}{c}\text { Yıldız } \\
\text { Teknik } \\
\text { Unniversitesi }\end{array}$ & MiM3212 & $\begin{array}{c}\text { Ahşabın Yapılarda } \\
\text { Kullanımı }\end{array}$ & 2 & 0 & 2 & 4 & 5,6 & Seçmeli \\
\hline Ders İçeriği & $\begin{array}{l}\text { Ahşap malzemenin özellikleri, Türkiye'de geleneksel ahşap yapılar, günümüz teknolojisi ile } \\
\text { üretilen ahşap yapıların sistem analizleri, yapım yöntemleri ve uygulama örnekleri. }\end{array}$ \\
\hline
\end{tabular}

Yıldız Teknik Üniversitesi Mimarlık Bölümü ders planında “Ahşabın Yapılarda Kullanımı” dersi beş ve altıncı yarıyılda seçmeli ders kapsamındadır (Çizelge 10). Söz konusu ders iki saatlik teorik kapsamda olup, içeriğini ahşap malzeme özellikleriyle birlikte geleneksel ahşap yapılar, endüstriyel ahşap yapı ürünleri, ahşap yapım sistemleri, oluşturmaktadır.

İstanbul Teknik Üniversitesi Mimarlık Bölümü ders planında "Wood in Arch. Design\&Construction” (Mimari Tasarım ve Yapımda Ahşap) dersi yedinci yarıyılda seçmeli ders kapsamında ve hâlihazırda İngilizce olarak yürütülmektedir (Çizelge 11). Söz konusu ders üç saatlik teorik kapsamda olup, içeriğini yapı malzemesi olarak ahşap özellikleriyle birlikte, ahşabın mimaride kullanımı, ahşap teknolojisi, yapı uygulamaları, Türkiye ve Dünya örneklerinin incelenmesi, ahşap ve yapı elemanları ve ilgili mevzuat oluşturmaktadır. 
Çizelge 11. İstanbul Teknik Üniversitesi Mimarlık Bölümü, "Wood in Arch. Design \& Construction" (Mimari Tasarım ve Yapımda Ahşap) dersi (İTÜ, 2018)

\begin{tabular}{|c|c|c|c|c|c|c|c|c|}
\hline $\begin{array}{c}\text { Üniversite } \\
\text { Adı }\end{array}$ & $\begin{array}{l}\text { Ders } \\
\text { Kodu }\end{array}$ & Ders Adı & Teori & Uygulama & Kredi & AKTS & Yariyıl & $\begin{array}{l}\text { Ders } \\
\text { Türü }\end{array}$ \\
\hline $\begin{array}{c}\text { İstanbul } \\
\text { Teknik } \\
\text { Üniversitesi }\end{array}$ & $\begin{array}{c}\text { MIM379 } \\
\text { E }\end{array}$ & $\begin{array}{l}\text { Wood in Arch. } \\
\text { Design\&Construc }\end{array}$ & 3 & 0 & 3 & 4 & 7 & Seçmeli \\
\hline $\begin{array}{l}\text { Ders İçeriği } \\
\text { **Ders içeriği } \\
\text { dersin } \\
\text { yürütücüsünde } \\
\text { n temin } \\
\text { edilmiştir. }\end{array}$ & \multicolumn{8}{|c|}{$\begin{array}{l}\text { Ahşabın mimaride kullanımı: taşıyıc1 sistem, yapı elemanları, kaplama, mobilya, bina dişı } \\
\text { kullanım; Yapı malzemesi olarak ahşap: teknik özellikler, performans testleri; Ahşap } \\
\text { teknolojisi: ağaç türleri, üretim, endüstriyel işlemler; Ahşap taşıııı sistemler; Ahşap } \\
\text { konstrüksiyon boyutlandırma, birleştirme yöntemleri; Ahşap ile ilgili kaynakça ve mevzuat; } \\
\text { Ahşap yapı uygulamaları: Türkiye ve dünyadan ahşap yapı örnekleri; Yapı elemanı olarak } \\
\text { ahşap: çatı, duvar, döşeme, kapı, pencere, merdiven; Ahşap yapıda servis sistemleri; Ahşap } \\
\text { yapıda alt sistemlerin bütünlenmesi. }\end{array}$} \\
\hline
\end{tabular}

Ahşap dersi bölümlerin bölüm/alan seçmeli ders havuzunda yer almakta ve birçoğunda ikinci sınıf 3. yarıyıldan itibaren alınabilmektedir (Çizelge 2, 6 ve 9). Dersler ikinci sınıf veya dördüncü sınıf seçmeli ders havuzunda da yer alabildiği gibi bazı üniversitelerde çoğu yarıyıllarda alınabilmektedir (Çizelge 1 ve 5). İncelenen ahşap ile ilgili ders örneklerinin tamamı seçmeli ders statüsündedir. Bazı üniversitelerde önkoşullu seçmeli ders olarak ders planında yer almaktadır. Ders adları ahşap yapı ve ahşap yapım sistemleri olarak ön plana çıkmaktadır. İki üniversitede (Sabahattin Zaim ve Mimar Sinan Güzel Sanatlar Üniversiteleri) ahşap konusunda iki farklı içerikte kurgulanmış ders bulunmaktadır (Çizelge 7 ve 9).

Mimarlık Lisans derecesi toplam asgari 240 AKTS ile sağlanmaktadır. Derslerin yerel kredi ve AKTS incelemesinde yerel kredi ve AKTS değerlerinin üniversiteler arası farklılık içerdiği görülmüştür. Bu değer yerel kredide 2-4 arası, AKTS olarak 3-5 arası değişkenlik göstermektedir. İncelenen örneklerde ders süresi çoğunlukla iki saattir. Diğerlerinde bu süre üç saate çıkmaktadır (Çizelge 1, 5, 6, 8 ve 11). Ahşap ile ilgili derslerin biri hariç ( Çizelge 6) tamamlı teorik kapsamdadır. Ders kataloglarındaki içeriklerden, teorik/uygulama yapısından bağımsız derslerde uygulamaların yer alabildiğini söylemek mümkündür.

Müfredatta yer alan derslerden ulaşılabilen içerik bilgileri derslerin tamamına yakınında malzeme özellikleri ile ilgili bilgilendirme yapıldığını göstermektedir. Geleneksel ahşap yap1 ve yapım sistemleri birçok derste yer bulmaktadır (Çizelge 2, 4, 6, 7, 8, 9 10). Bununla birlikte geleneksel ahşap yapılar, ahşap sivil mimarlık örnekleri kendi başına bir ders içeriği oluşturacak kadar kapsamlı ele alınabilir özelliktedir. Ahşap ve ahşap yapılara ilişkin yönetmelik ve standart bilgisi derslerin büyük kısmında yer aldığı görülmektedir. Yapısal ahşap konusu, birleşim ve birleşim araçları gibi konular ise benzer şekilde bazı dersler kapsamında ele alınmıştır.

Mimarlık bölümü sayısı ve kontenjan açısından ülkedeki toplam kapasitenin önemli bir bölümü İstanbul'dadır. Mimarlık eğitimi açısından İstanbul önemli bir merkez olarak görünmektedir. Aynı şekilde, ahşap mimarlık miras örnekleri açısından da İstanbul öne çıkan kentlerden biridir. Bununla birlikte ahşap yapılar konusunda mimarlık bölümlerinde bağımsız ders, az sayıda üniversitede yer almaktadır. Yapı malzemesi, yapı elemanları ve mimari 
tasarım derslerinde kısmi olarak yer alabilen ahşaba, bağımsız ders olarak da mimarlık bölümlerinde daha fazla yer verilmesi ahşabın mimarideki konumunu güçlendirecektir. Bunun yanında eğitimin ahşapla ilişkili üretim bölgeleriyle bağlantılı biçimde diğer disiplinlerle geliştirilebilmesi, üretimden tasarıma bütünsel bakışa olanak sağlayabilir. Üretim merkezleriyle bütünleşmiş ve gelişmiş ahşap yapı kültürünün eğitimle daha çok temas halinde olması ve bilgi alışverişi, ahşap yapı kültürünün sürekliliğinde katkı sağlayıcı etki oluşturabilir. Bağımsız ders içerikleri ahşabın ve ana kaynağı ağacın özelliklerine odaklıdır. Teorik ders olması tasarım ve uygulama ile bütünleştirmede ilave zaman veya devamlılık içeren ders gerektirmektedir. Derslerin tamamı seçmeli olması, seçmeli havuzundaki alternatiflere bağlı olarak ilgiyi değişken kılmaktadır. Geleneksel ahşap yapı sistemlerinden günümüz yapım sistemlerine kadar öğrencilerin konuyu tasarım aşamasında ele alabilmeleri, öğrenme sürecinde meslekle bağlantılı ilgili alanlarının seçimini de destekleyici olabileceği düşünülmektedir.

\section{Sonuçlar ve Öneriler}

- İstanbul'da bulunan mimarlık bölümleri kapsamında yapılan araştırma sonuçlarına göre; ahşap ve ahşap yapılar konusunun mimarlık lisans eğitiminde yeterince bulunduğuna ilişkin güçlü bir veri saptanamamıştır.

- Mimarlık meslek eğitiminde restorasyon, yapı elemanları, yapı malzemesi gibi dersler dışında daha fazla sayıda ahşap ve ahşap yapılar konusunda bağımsız derslerin olması, ahşap konusuna ilginin artmasında olumlu etki sağlar.

- Öğrencilerin mimari tasarım atölyelerinde geliştirdikleri tasarımları ahşap malzeme ile bütünleştirebilmesine yönelik uygulama olanakları, konuyu çok yönlü irdelenebilmesinde katkı sağlayabilir.

- Mimarlık meslek alanı ile birlikte diğer ilgili disiplinlerle ortaklaşa çalışmalar ahşabın çok yönlü ele alınması açısından önemli katkı sağlayabilir.

- Ahşap mimarlık mirasının korunmasında, ahşap yapı malzemesi ve yapım sistemlerini tanımak ve yeni tasarımlarla buluşturmak önemli olmaktadır.

- Ahşap, kaynağı ağaç ve ormanla birlikte insanlığın varoluşundan bugüne insan yaşamının her bölümünde yer almıştır. $\mathrm{Bu}$ durumun devamlılı̆̆ının sağlanması önemsenmelidir.

- Mimarlık Fakültelerinde ahşabın esas alındığı özel programların kurgulanması, yeni teknoloji, tarihi yapı, malzeme laboratuarı, tasarım ve uygulama içeren programların geliştirilmesi, ahşabın uygun kullanımı ve ahşap mirasın korumasına katkı sağlayabilir.

- İstanbul merkezli yapılan çalışmanın Türkiye geneli için de yapılması ve bu alandaki eğitimcilerin, üretici ve uygulamacıların görüşlerinin alınması programların geliştirilmesine katkı sağlayabilir. 


\section{Kaynaklar}

Aalto University. (2018), The Department of architecture at Aalto university, wood program. Aalto university, http://woodprogram.fi/introduction/

Acton Ostry Architects. (2018), Brock commons tallwood house. acton ostry architects: https://www.actonostry.ca

Akça, C., Akarca, H., Erdoğmuş, E., \& Demirel, A. (2018), Yapı ahşabı ve ahşap yapı sektörü (2013-2014). Ulusal Ahşap Birliği UAB: http://www.ahsap.org

ARKIV. (2018), Afet bölgeleri için taşınabilir okul yapıları, 1999. Arkiv: http://www.arkiv.com.tr

Bern University of Applied Science. (2018), Bachelor of science in wood engineering. Bern university of applied science, https://www.ahb.bfh.ch

Doğuş Üniversitesi. (2018), Ders programı, sanat ve tasarım fakültesi, mimarlık bölümü, https://www.dogus.edu.tr

Fatih Sultan Mehmet Üniversitesi. (2018), Ders planı, mimarlık ve tasarım fakültesi, mimarlık bölümü, http://www.fsm.edu.tr

Eldem, H., S. (1933), Amca Hüseyin Paşa yalısı. Arkitekt 1933(12), 377-381.

Haliç Üniversitesi. (2018), Ders planı, mimarlık fakültesi. mimarlık bölümü, https://obs.halic.edu.tr

ICOMOS (2017), Principles for the conservation of wooden built heritage. Retrieved from ICOMOS international council on monuments and sites, https://www.icomos.org

İstanbul Büyükşehir Belediyesi. (2018), İstanbul yangınları. İstanbul itfaiyesi, http://itfaiye.ibb.gov.tr

İstanbul Gelişim Üniversitesi. (2018), Ders planı. mühendislik ve mimarlık fakültesi. mimarlık bölümü, http://gbs.gelisim.edu.tr

İstanbul Kültür Üniversitesi. (2018), Program ders planı. mimarlık fakültesi. mimarlık bölümü, https://legacy.iku.edu.tr

İstanbul Sabahattin Zaim Üniversitesi. (2018), Ders planı ve AKTS kredileri. mühendislik ve doğa bilimleri fakültesi. mimarlık bölümü: https://www.izu.edu.tr

İstanbul Ticaret Üniversitesi. (2018), Müfredat raporu, mimarlık ve tasarım fakültesi: https://www.ticaret.edu.tr

İTÜ. (2018), Ders Planı, mimarlık fakültesi, mimarlık bölümü: http://www.sis.itu.edu.tr

Kuban, D. (1973). Türkiye'de ve özellikle istanbul'da ahşap konut mimarisi ve korunması ile ilgili sorunlar. Mimarlık Dergisi 1973(6), 15-16.

MEB. (2018), Meslekî ve teknik Eğitim Genel Müdürlügüu, Milli Eğitim Bakanlığg: http://mtegm.meb.gov.tr

Medipol Üniversitesi. (2018), Mimarlık programı. güzel sanatlar tasarım ve mimarlık fakültesi - mimarlık programı: https://mebis.medipol.edu.tr

Mimar Sinan Güzel Sanatlar Üniversitesi . (2018), Ders planı, mimarlık fakültesi, mimarlık bölümü, http://www.msgsu.edu.tr

Oran Mimarlık. (2018), Marmara taşınabilir ahşap deprem okulları - marmara 1999. Oran Mimarlık: http://www.oranmimarlik.com.tr

Ordu Kültür ve Turizm Müdürlüğü. (2018), Ordu çivisiz camii. Ordu kültür ve turizm müdürlüğ̈̈: http://www.ordukulturturizm.gov.tr

ÖSYM. (2018). 2018 Yükseköğretim programları ve kontenjanlar kılavuzu. öğrenci seçme ve yerleştirme merkezi: http://www.osym.gov.tr

Pervititch, J. (2000), Sigorta haritalarında İstanbul. İstanbul: Axa-Oyak, Tarih vakfı yurt yayınları.

Rosenheim University of Applied Sciences. (2018), Technology studies, rosenheim university of applied sciences, https://www.th-rosenheim.de 
Sumitomo Forestry. (2018), Changing cities into forests: creating environmentally-friendly and timber-utilizing cities, sumitomo forestry Co., Ltd, http://sfc.jp

Tamer, C. (1947), Kanlıca'daki Amcazade Hüseyin Paşa yalısı ve yapılan onarım, Arkitekt, 1947(11-12), 248-251.

TUM. (2018), Professorship of architectural design and timber construction. Technical university of Munich, department of architecture, https://www.ar.tum.de

Türkiye Kültür Portalı. (2018), Beyşehir Eşrefoğlu câmii ve külliyesi, Konya, Kültür ve Turizm Bakanlığ1-Türkiye Kültür Portalı: https://www.kulturportali.gov.tr

UAB, (2014), Ulusal Ahşap Birliği, http://www.ahsap.org/

URL1 https://makovecz.hu/makoveczimre/epuletek/1995-piliscsaba-stefaneum/

URL2 https://www.archdaily.com/199442/gc-prostho-museum-research-center-kengo-kumaassociates

URL3 http://www.shigerubanarchitects.com/works/2017_fujisan/index.html

URL4 http://www.nsmh.com/proje_detay.asp?lang=tr\&ID $=55$

URL5 http://www.nasreddingroup.com/cpanel/galeri.php?proid=1

URL6 http://www.burostatik.com/mobile/eng/catalhoyuk-korugan-yapisi.asp?id=109\&id2=22

Waugh Thistleton Architects. (2018), Murray grove the original timber tower. waugh thistleton architects, http://waughthistleton.com

Yıldız Teknik Üniversitesi. (2018), Dersler. mimarlık fakültesi. mimarlık bölümü. mimarlık bölümü, http://www.bologna.yildiz.edu.tr

YÖK. (2018), Yükseköğretim bilgi yönetim sistemi, yükseköğretim istatistikleri, yükseköğretim kurulu, https://istatistik.yok.gov.tr/ 